\title{
Evaluation of the Relationship Between Saphenous Vein Graft Disease and Triglyceride Glucose Index
}

\author{
Safen Ven Greft Hastalı̆ı̆ ile Trigliserit Glukoz Indeksi Arasındaki Ilișkinin Değerlendirilmesi
}

\author{
Armagan Acele, Ozge 0zcan Abacioglu \\ Department of Cardiology, Adana City Training and Research Hospital, Adana, Turkey
}

\begin{abstract}
Aim: It is known that insulin resistance, one of the main components of metabolic syndrome, is associated with endothelial dysfunction and related diseases. Insulin resistance can be evaluated by HOMA-IR and indirectly by triglyceride-glucose (tg-glucose) index. We aimed to investigate the relationship between saphenous vein graft disease (SVGD) and tg-glucose index.
\end{abstract}

Material and Method: 418 patients who underwent coronary angiography in our clinic between January 2019 and December 2020 and had a history of coronary artery bypass grafts were included retrospectively. The patients were divided into two as those with $50 \%$ or more stenosis in at least one of their SVG (SVGD group) and those without (control group). Tg-glucose index was calculated by the formula In (fasting $\operatorname{tg} X$ fasting glucose/2). A value of $P<0.05$ was considered statistically significant.

Results: The mean age of 185 patients in the SVGD group was $67.3 \pm 4.3$ (25.9\% female), and the mean age of 233 patients in the control group was $66.4 \pm 8.2$ (25.7\% female). The ejection fraction values of the patients in the SVGD group were lower than the control group $(51.6 \pm 9.0 \% \& 55.9 \pm 6.5, p<0.001)$ and serum creatinine, $C R P$, triglyceride, glucose and tg-glucose index values were higher $(p=0.041, p=0.003, p<0.001, p<0.001$ and $p<0.001$, respectively). In multivariate logistic regression analysis, low EF, high serum triglyceride and glucose values and tg-glucose index were found to be associated with SVGD. Pairwise comparison of ROC curve analysis revealed that tg-glucose index had better performance than glucose or triglyceride levels to predict SVGD.

Conclusion: Tg-glucose index is a biomarker that can be calculated from routine biochemistry tests and can give better results than serum glucose and triglyceride values in predicting SVGD.

Key words: coronary artery bypass; saphenous vein graft; triglyceride-glucose index

ÖZET

Amaç: Metabolik sendromun ana bileșenlerinden biri olan insülin direncinin endotel disfonksiyonu ve ilișkili hastalıklar ile bağlantılı olduğu bilinmektedir. Insülin direnci HOMA-IR ve indirekt olarak da trigliserit-glukoz (tg-glukoz) indeksi ile değerlendirilebilmektedir. $\mathrm{Bu}$ çalıșmanın amacı, safen ven greft hastalığı (SVGH) ile tg-glukoz indeksi arasındaki ilișkiyi araștırmaktır.

Materyal ve Metot: 2019-2020 yıllarında kliniğimizde koroner anjiyografi yapılan ve koroner arter bypass greft öyküsü olan 418 hasta çalıșmaya retrospektif olarak dahil edildi. Hastalar SVG'lerinden en az birinde \%50 veya fazla darlık olanlar (SVGH grubu) ve olmayanlar (kontrol grubu) șeklinde ikiye ayrıldı. Tg-glukoz indeksi In (açlık tg X açlık glukoz/2) formülü ile hesaplandı. $P<0,05$ değeri istatistiksel olarak anlamlı kabul edildi.

Bulgular: SVGH grubundaki 185 hastanın yaș ortalaması 67,3 $\pm 4,3$ (\%25,9 bayan), kontrol grubundaki 233 hastanın yaș ortalaması $66,4 \pm 8,2$ (\%25,7 bayan) idi. SVGH grubundaki hastaların ejeksiyon fraksiyonu değerleri kontrol grubuna göre daha düșükken (\%51,6 $\pm 9,0$ \& \%55,9 $96,5, p<0,001)$; serum kreatinin, CRP, trigliserit, glukoz ve tg-glukoz indeksi değerleri daha yüksekti (sırasıyla; $p=0,041, p=0,003, p<0,001, p<0,001$ ve $p<0,001)$. Çok değișkenli lojistik regresyon analizinde düșük $E F$, yüksek serum trigliserit ve glukoz değerleri ile tg-glukoz indeksi SVGH ile ilișkili bulundu. ROC eğrisi analizinin ikili karșılaștırması, tg-glukoz indeksinin SVGH'yi tahmin etmek için glukoz ve trigliserit değerlerine göre daha iyi performansa sahip olduğunu ortaya koydu.

Sonuç: Tg-glukoz indeksi rutin biyokimya tetkiklerinden hesaplanabilen, SVGH'nı öngörmede serum glukoz ve trigliserit değerlerinden daha iyi sonuç verebilecek bir biyobelirteçtir.

Anahtar kelimeler: koroner arter bypass; safen ven grefti; trigliserit-glukoz indeksi

\section{Introduction}

There are studies showing that chronic inflammatory process is effective in the development of insulin resistance ${ }^{1-3}$. It is known that insulin resistance triggers endothelial dysfunction by increasing oxidative stress and causes dyslipidemia by affecting lipid metabolism ${ }^{4,5}$.

Iletișim/Contact: Özge Özcan Abacıoğlu, Adana Şehir Eğitim ve Araştırma Hastanesi, Kardiyoloji Ana Bilim Dal, Adana, Türkiye • Tel: 05326486280 • E-mail: ozgeozcan83@yahoo.com.tr • Geliș/Received:28.05.2021 • Kabul/Accepted: 04.11.2021

ORCID: Armağan Acele, 0000-0002-8535-7855 • Özge Özcan Abacioğlu, 0000-0003-1392-9380 
The process consisting of endothelial dysfunction, dyslipidemia and chronic inflammation is the basis of atherosclerosis ${ }^{6,7}$. Therefore, insulin resistance is associated with coronary artery disease both directly and indirectly. Determining whether the host has insulin resistance and its level is also important in terms of the treatment approach. The fact that it is a calculable parameter from laboratory data has made the use of HOMA-IR widespread in daily practice ${ }^{8,9}$. Apart from the HOMA-IR level, the tg-glucose index, which can be calculated using serum triglyceride and glucose levels, can indirectly provide information about insulin resistance ${ }^{10}$. It has been shown to be associated with atherosclerosis better than HOMA-IR ${ }^{11}$.

SVGs, which are widely used in coronary artery bypass surgery, can remain less patented than arterial grafts due to the peculiar characteristics of the venous system ${ }^{12}$. It has been shown that $60 \%$ of saphenous grafts remained patents after 10 years, and $50 \%$ of them had severe stenosis ${ }^{13}$. Thrombosis, intimal hyperplasia and atherosclerosis are involved in the pathogenesis of vein graft disease. While the frequency of thrombosis is high in the early postoperative period, atherosclerosis plays a dominant role in the later period $^{14}$. It is known that insulin resistance is effective in the development of atherosclerosis, and it has been shown that the risk can be reduced with treatments that reduce insulin resistance ${ }^{15}$. The aim of this study is to investigate the relationship between tg-glucose index, which can give information about the insulin resistance, and SVGD.

\section{Material and Methods}

418 patients who underwent coronary angiography in our clinic between January 2019 and January 2021 and had a history of coronary artery bypass graft were included in the study. Patients were divided into two groups: those with $50 \%$ or more stenosis in at least one of the saphenous vein grafts as the SVGD group, and those without stenosis as the control group. Systolic heart failure, left ventricular ejection fraction $<40 \%$; Hypertension was defined as patients' systolic and diastolic blood pressure $>140 / 90 \mathrm{mmHg}$ or the patient's use of any anti-hypertensive medication. Diabetes mellitus (Type 2 DM) was defined as having a previous diagnosis of DM or using anti-diabetic medication or a fasting blood glucose $>126 \mathrm{mg} / \mathrm{dL}$ or $\mathrm{HbAl} \mathrm{c}>6.5 \%$. At least 8-hour fasting venous blood samples were taken from the patients and analyzed using appropriate methods. Routine biochemistry, complete blood values, and lipid profile results were recorded. Tg-glucose index was calculated using the formula $\ln$ (fasting tg $\mathrm{X}$ fasting glucose/2). Patients with a diagnosis or suspicion of coronavirus-19, hematological disease or malignancy, chronic liver failure, autoimmune disease, and rheumatological disease or incomplete laboratory results were excluded from the study.

The study was approved by the local Clinical Research Ethics Committee of our hospital (20.5.2021/1412) and the study protocol was prepared in accordance with the ethical rules of the 1975 Helsinki Declaration.

\section{Statistical Analysis}

All statistical analyses were performed with SPSS 17 (SPSS, Inc., Chicago, Illinois, USA) and MedCalc v. 19.6.1. Continuous variables were exoressed as mean \pm standard deviation (mean \pm SD) or median (interquartile range); categorical variables were expressed as numbers and percentages. Comparison of continuous variables between groups was performed using t-test and Mann-Whitney U test or the $\chi 2$ test or Fisher's Exact test for categorical variables. Whether the continuous variables had a normal distribution was analyzed using the Shaphiro-Wilk test. Variables with a $p$ value of $\leq 0.01$ in the univariate analysis were included in the multivariate analysis. Results are expressed as relative risk and $95 \%$ confidence interval (CI). A p value of less than 0.05 was considered statistically significant.

\section{Results}

The mean age of the patients included in the study was $66.8 \pm 6.7$ ( $74.1 \%$ male). 185 patients with $50 \%$ or more stenosis in at least one of the saphenous vein grafts were included in the SVGD group, and 233 patients without stenosis were included in the control group. There was no statistically significant difference between SVGD group and control group in terms of basal demographic characteristics. The mean ejection fraction values of the patients in the SVGD group were lower than the control group $(51.6 \pm 9.0 \% \& 55.9 \pm 6.5, \mathrm{p}<0.001)$; serum creatinine, CRP, triglyceride, glucose and tg-glucose index values were found to be higher than the control group $(\mathrm{p}=0.041, \mathrm{p}=0.003, \mathrm{p}<0.001, \mathrm{p}<0.001$ and $\mathrm{p}<0.001$, respectively). The demographic characteristics of the patients included in the study and the comparison of laboratory results are summarized in Table 1 . 
Multivariate regression analysis (Model 1) in which triglyceride, glucose values and other variables were taken and another regression analysis (Model 2) in which triglyceride and glucose values were excluded and other variables were taken with $\mathrm{Tg}$-glucose index were used to analyze variables that could predict SVGD. According to Model 1, low ejection fraction, serum triglyceride and glucose values were found to be predictors for SVGD; In model 2, tg-glucose index and again low ejection fraction were found to be associated with SVGD (Table 2).

Table 1. Comparison of demographic properties and laboratory results of groups

\begin{tabular}{|c|c|c|c|}
\hline & SVGD group $(n=185)$ & Control group $(n=233)$ & $\mathrm{p}$ \\
\hline Age, years & $67.3 \pm 4.3$ & $66.4 \pm 8.2$ & 0.237 \\
\hline Female, $\mathrm{n}(\%)$ & $48(25.9)$ & $60(25.7)$ & 0.985 \\
\hline Diabetes Mellitus, \% & 57 & 56.8 & 0.999 \\
\hline Hypertension, \% & 71.8 & 73 & 0.836 \\
\hline ESRD or GFR $\leq 45 \mathrm{ml} / \mathrm{min} / 1.73 \mathrm{~m}^{2}, \%$ & 4.2 & 3.2 & 0.726 \\
\hline Systolic BP, mm Hg & $127.4 \pm 17.3$ & $122.9 \pm 12.4$ & 0.108 \\
\hline Diastolic BP, mm Hg & $78.8 \pm 9.7$ & $74.0 \pm 8.3$ & 0.497 \\
\hline LVEF, \% & $51.6 \pm 9.0$ & $55.9 \pm 6.5$ & 0.001 \\
\hline Hemoglobin, g/dL & $13.2 \pm 1.8$ & $13.1 \pm 1.8$ & 0.646 \\
\hline WBC, $10^{3} / \mathrm{mL}$ & $8.4 \pm 2.1$ & $8.5 \pm 2.0$ & 0.529 \\
\hline PLT, $10^{3} / \mathrm{mL}$ & $232.2 \pm 66.5$ & $238.1 \pm 62.2$ & 0.356 \\
\hline Glucose, mg/dL & $162.9 \pm 71.1$ & $123.2 \pm 41.5$ & $<0.001$ \\
\hline Urea, mg/dL & $42.3 \pm 17.6$ & $38.6 \pm 14.2$ & 0.186 \\
\hline Creatinine, $\mathrm{mg} / \mathrm{dL}$ & $1.0 \pm 0.7$ & $0.9 \pm 0.4$ & 0.041 \\
\hline $\mathrm{LDL}, \mathrm{mg} / \mathrm{dL}$ & $126.9 \pm 35.5$ & $124.8 \pm 35.0$ & 0.545 \\
\hline $\mathrm{HDL}, \mathrm{mg} / \mathrm{dL}$ & $38.6 \pm 8.2$ & $39.2 \pm 7.3$ & 0.481 \\
\hline Triglyceride, $\mathrm{mg} / \mathrm{dL}$ & $210.1 \pm 105.2$ & $170.1 \pm 97.8$ & $<0.001$ \\
\hline CRP, median (IQR) & $5.6(14.5)$ & $2.5(5.6)$ & 0.003 \\
\hline Tg-glucose index & $5.1 \pm 0.2$ & $4.8 \pm 0.2$ & $<0.001$ \\
\hline Albumin, g/dL & $3.8 \pm 0.4$ & $3.8 \pm 0.3$ & 0.146 \\
\hline Acetylsalicylic acid,\% & 80.8 & 85.7 & 0.335 \\
\hline Statin, \% & 62.7 & 63.4 & 0.912 \\
\hline Beta blocker, \% & 86.1 & 86.5 & 0.942 \\
\hline ACEI/ARB, $\%$ & 77.6 & 69.8 & 0.195 \\
\hline
\end{tabular}

ACEl, angiotensin converting enzyme inhibitors; ARB, angiotensin receptor blockers; BP, blood pressure; CRP, C-reactive protein; ESRD, end stage renal disease; GFR, glomerular filtration rate; HDL, high density lipoprotein cholesterol; LDL, low density lipoprotein cholesterol; LVEF, left ventricle ejection fraction; Tg, triglyceride; PLT, platelets; WBC, white blood cell count.

Table 2. Univariate and multivariate regression analysis

\begin{tabular}{|c|c|c|c|c|}
\hline & \multicolumn{2}{|c|}{ Univariate analysis } & \multicolumn{2}{|c|}{ Multivariate analysis } \\
\hline & OR $(95 \% \mathrm{Cl})$ & $p$ & OR $(95 \% \mathrm{Cl})$ & $p$ \\
\hline Glucose & $1.013(1.009-1.017)$ & $<0.001$ & $1.013(1.006-1.019)$ & $<0.001^{*}$ \\
\hline Triglyceride & $1.004(1.002-1.006)$ & $<0.001$ & $1.006(1.002-1.009)$ & $0.002^{*}$ \\
\hline EF & $0.933(0.900-0.968)$ & $<0.001$ & $0.927(0.888-0.967)$ & $<0.001^{\star \star}$ \\
\hline $\begin{array}{l}\text { CRP } \\
\text { Creatinine }\end{array}$ & $\begin{array}{l}1.017(1.017-1.029) \\
1.646(1.067-2.539)\end{array}$ & $\begin{array}{l}0.004 \\
0.024\end{array}$ & $1.004(0.980-1.029)-$ & 0.726 \\
\hline Tg-glucose index & $25.03(10.77-58.13)$ & $<0.001$ & $48.86(14.05-169.91)$ & $<0.001^{\star \star}$ \\
\hline
\end{tabular}

CRP, C-reactive protein; EF, ejection fraction; $\mathrm{Tg}$, triglyceride.

* Model 1: EF, triglyceride, glucose, CRP.

** Model 2: EF, tg-glucose index, CRP. 


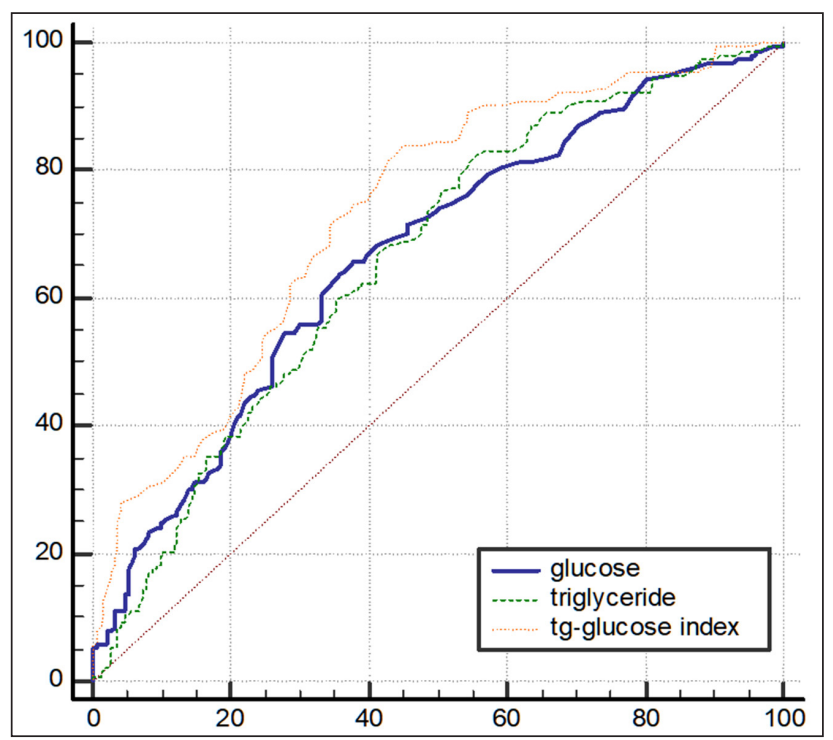

Figure 1. ROC curve analysis of glucose, triglyceride and tg-glucose index.

Pairwise comparison of ROC curve analysis showed that the predictive power of tg-glucose index of SVGD was better than serum triglyceride and glucose levels (tg-glucose index and glucose: difference between area under curve [AUC]: 0.0650, SE: 0.0310 , z statistics 2.097 and $p=0.0360$; tg-glucose index and triglyceride: difference between AUC: 0.0700, SE: 0.0237, z statistics: 2.954 and $p=0.0031$; triglyceride and glucose: difference between AUC: 0.00492, SE: 0.0426, $\mathrm{z}$ statistics 0.115 and $\mathrm{p}=0.9081$ ) (Fig. 1).

\section{Discussion}

The most important results of this study are; 1) Insulin resistance is associated with coronary artery disease, and this relationship is also valid for SVGD, 2) The risk of stenosis in SVGs of patients with low ejection fraction is higher than those with normal EF, 3) Serum triglyceride and glucose values and tg-glucose index, which is a biomarker calculated using serum triglyceride and glucose levels and gives information about insulin resistance, was found to be higher than control patients, 4) Tg-glucose index was better than serum glucose and triglyceride levels in predicting SVGD in ROC curve analysis, 5) Tg-glucose index which can be calculated using routine biochemistry studies, is associated with SVGD and is a biomarker that can be used to determine the SVGD in daily practice.

Insulin resistance is a condition that may result in type $2 \mathrm{DM}$, coronary artery disease, polycystic ovary syndrome, metabolic syndrome, and obesity-related malignancy ${ }^{16}$. Insulin resistance, which is assumed to be chronic inflammation in pathogenesis, leads to the formation of a vicious circle as it leads to an increase in the inflammatory process. Its relationship with coronary artery disease can be explained by the fact that increased serum glucose and insulin levels trigger oxidative stress and cause dyslipidemia due to its effect on lipid metabolism ${ }^{17}$. Nitric oxide (NO), which is known to be an important vasodilator and anti-oxidative molecule, stimulates glucose transport in muscle and adipose tissue and increases glucose oxidation while reducing hepatic glycogen synthesis. In insulin resistance state, the NO synthesis stimulated by insulin is selectively impaired $^{18}$. In patients with a high Tg-glucose index, arterial stiffness was also detected higher and this indicates that the level of nitric oxide in this group may be lower ${ }^{19}$. In addition, the level of ntric oxide is inversely related to the severity of the disease in patients with acute coronary syndromeand the fact that it was found to be even lower in those who underwent coronary bypass compared to those who underwent percutaneous intervention; suggests that the triglyceride glucose index may be higher in these patients ${ }^{20}$. SVGD develops on the basis of thrombosis or intimal hyperplasia in the early postoperative period and atherosclerosis in the period after 1 year. Therefore, it is possible to think that risk factors of atherosclerosis such as DM, HT, smoking and age are also valid for SVGD.

Within 10 years after coronary artery bypass operation using SVG, up to $20 \%$ of patients need revascularization $^{21}$. Lesions and restenosis evaluated as noncritical in coronary angiography cause chronic angina in most of the patients. Although DM, which is a major risk factor for atherosclerosis, has been identified as an independent risk factor for SVGD in some studies, there are also studies suggesting that this theory is not valid ${ }^{22,23}$. In our study, patients in the group with and without SVGD were found to be similar in terms of the frequency of DM. The thesis that high blood glucose level is inversely related to SVG patency, whether DM is diagnosed or not, was also demonstrated in our study.

Kubiak et al. found that patients with SVG stenosis had a lower ejection fraction in the study in which optical coherence tomography was used ${ }^{24}$. Our study also supports these results.

The relationship between high serum LDL and low HDL and SVGD has been emphasized in studies ${ }^{25,26}$. 
The results of our study do not support these data. In obtaining these results; it should be kept in mind that the LDL levels of the patients in both groups were above the targeted value and that the rate of statin use was $63 \%$. The result that the frequency of SVGD is higher in patients with high triglycerides compared to the control group was also shown in our study.

Tg-glucose index is a biomarker that can be calculated from routine biochemistry tests and can provide indirect information about insulin resistance. The fact that the insulin level can be calculated according to the HOMA-IR value without the need increases the usability rate of this index. The relationship of high tg-glucose index with the presence, severity and prognosis of coronary artery disease has been demonstrated in many studies. Mao et al. conducted a study of 791 non-ST elevation acute coronary syndrome patients and followed all patients for 12 months and showed that high tg-glucose index was a risk factor for the development of major cardiovascular events ${ }^{27}$. Another study in which 2840 patients evaluated with coronary computed tomographic angiography were included. In the study, it was found that the tg-glucose index was associated with coronary artery disease ${ }^{28}$.

Our study also shows that the tg-glucose index is significantly higher in patients with SVGD compared to controls and is better in predicting the disease than glucose and triglyceride levels.

This study has multiple limitations such as being single centered and retrospective. The HOMA-IR level could not be calculated because the insulin level was not routinely studied in the patients, and the tgglucose index and the HOMA-IR level could not be compared. The data in our study should be supported by prospective, multicenter and studies including comparative results.

\section{References}

1. Savaş HB, Gültekin F. İnsülin Direnci ve Klinik Önemi- Insulin Resistance and Clinical Significance. Med J SDU/SDÜ Tıp Fak Derg 2017:24:116-25. doi:10.17343/sdutfd.264358

2. Das UN. Is metabolic syndrome $X$ an inflammatory condition? Exp Biol Med (Maywood)2002;227:989-97. doi: $10.1177 / 153537020222701106$

3. Yalcın T, Rakıcioglu N. Diyetsel Etmenler, Tip 2 Diyabet ve İnflamasyon- Dietary Factors, Type 2 Diabetes and Inflammation. Sakarya Tip Dergisi 2018;8:686-94.
4. Günel T, Göksever Çelik H, Diz Küçükkaya R, Alkaç İM, Aydınlı K. İnsan Hastalıklarında Endotel Fonksiyon ve Disfonksiyonunun Moleküler Mekanizmalar1-Molecular Mechanisms of Endothelial Function and Dysfunction in Human Diseases. İKSSTD 2020;12:201-16. doi: 10.5222/ iksstd.2020.61587

5. Öztürk Z. Diabetes, Oxidative Stress and Endothelial Dysfunction. Bezmialem Science 2018. doi: 10.14235/ bs. 2018.2145

6. Yaylalı YT, Küçükaslan M. Endotel disfonksiyonu Endothelial dysfunction. Pamukkale Tip Dergisi 2011;4:152-7.

7. Sitia S, Tomasoni L, Atzeni F, Ambrosio G, Cordiano C, Catapano A, et al. From endothelial dysfunction to atherosclerosis. Autoimmun Rev 2010;9:830-4. doi: 10.1016/j. autrev.2010.07.016

8. Mojiminiyi OA, Abdella NA. Effect of homeostasis model assessment computational method on the definition and associations of insulin resistance. Clin Chem Lab Med 2010;48:1629-34.

9. Antuna-Puente B, Disse E, Rabasa-Lhoret R, Laville M, Capeau J, Bastard JP. How can we measure insulin sensitivity/resistance? Diabetes Metab 2011;37:179-88.

10. Simental-Mendía L. E, Rodríguez-Morán M, Guerrero-Romero F. The product of fasting glucose and triglycerides as surrogate for identifying insulin resistance in apparently healthy subjects. Metabolic Syndrome and Related Disorders 2008;6:299-304. doi: $10.1089 /$ met.2008.0034

11. Irace C, Carallo C, Scavelli FB, De Franceschi MS, Esposito T, Tripolino C, et al. Markers of insulin resistance and carotid atherosclerosis. A comparison of the homeostasis model assessment and triglyceride glucose index. Int J Clin Pract 2013;67:665-72. doi: 10.1111/ijcp.12124

12. Motwani JG, Topol EJ. Aortocoronary saphenous vein graft disease: pathogenesis, predisposition, and prevention. Circulation 1998;97:916-31.

13. Nieman K, Pattynama PMT, Rensing BJ, Van Geuns RJM, De Feyter PJ. Evaluation of patients after coronary artery bypass surgery: CT angiographic assessment of grafts and coronary arteries. Radiology 2003;229:749-56. doi: 10.1148/ radiol.2293020856

14. Gökay S, Çiçek D. Safen ven grefti hastalığı; nedenleri, önlenmesi ve tedavisinde güncel yaklaşımlar-Saphenous vein graft disease: causes, prevention, and contemporary treatment strategies. Türk Kardiyol Dern Arş- Arch Turk Soc Cardiol 2012;40:736-43. doi: 10.5543/tkda.2012.26790

15. Di Pino A, DeFronzo RA. Insulin Resistance and Atherosclerosis: Implications for Insulin-Sensitizing Agents. Endocr Rev 2019;40:1447-67. doi: 10.1210/er.2018-00141

16. Özer EM. İnsülin direnci-Insulin resistance. Maltepe Tip Dergisi/Maltepe Medical Journal 2015;2:1-5.

17. Laakso M, Kuusisto J. Insulin resistance and hyperglycaemia in cardiovascular disease development. Nat Rev Endocrinol 2014;10:293-302. doi: 10.1038/nrendo.2014.29 
18. Ormazabal V, Nair S, Elfeky O, Aguayo C, Salomon C, Zuñiga FA. Association between insulin resistance and the development of cardiovascular disease. Cardiovasc Diabetol 2018;17:122. doi: 10.1186/s12933-018-0762-4

19. Wu S, Xu L, Wu M, Chen S, Wang Y, Tian Y. Association between triglyceride-glucose index and risk of arterial stiffness: a cohort study. Cardiovasc Diabetol 2021;20:146. doi: 10.1186/ s12933-021-01342-2

20. Acara, A. Ç, Bolatkale, M. Endothelial nitric oxide level as a predictor of coronary complexity in patients with unstable angina pectoris. Am J Med Sci 2019;357:453-60. https:// dx.doi.org/10.1016/j.amjms.2019.02.011

21. Halabi AR, Alexander JH, Shaw LK, Lorenz TJ, Liao L, Kong DF, et al. Relation of early saphenous vein graft failure to outcomes following coronary artery bypass surgery. Am J Cardiol 2005;96:1254-9. doi: 10.1016/j.amjcard.2005.06.067

22. Gao J, Liu Y, Li YM. Review of risk factors, treatment, and prevention of saphenous vein graft disease after coronary artery bypass grafting. J Int Med Res 2018;46:4907-19. doi: $10.1177 / 0300060518792445$

23. Koshizaka M, Lopes RD, Reyes EM, Gibson CM, Schulte PJ, Hafley GA, et al. Long-term clinical and angiographic outcomes in patients with diabetes undergoing coronary artery bypass graft surgery: results from the Project of Ex-vivo Vein Graft Engineering via Transfection IV trial. Am Heart J 2015;169:175-84. doi: 10.1016/j.ahj.2014.10.013.Epub 2014 Oct 23
24. Kubiak GM, Pociask E, Wańha W, Dobrolińska M, Gąsior P, Smolka G, et al. Saphenous graft atherosclerosis as assessed by optical coherence tomography data for stenotic and nonstenotic lesions from the OCTOPUS registry Postepy Kardiol Interwencyjnej 2018;14:157-66. doi: 10.5114/aic.2018.76407

25. Jerzewski K, Ruel M, Voisine P, Le May MR, Kulik A. Does high-density lipoprotein influence the development of saphenous vein graft disease after coronary bypass surgery?: exploratory analysis from the CASCADE trial. J Cardiothorac Surg 2013;8:172. doi: 10.1186/1749-8090-8-172

26. Hata M, Takayama T, Sezai A, Yoshitake I, Hirayama A, Minami K, et al. Efficacy of aggressive lipid controlling therapy for preventing saphenous vein graft disease. Ann Thorac Surg 2009;88:1440-4. doi: 10.1016/j.athoracsur.2009.06.009

27. Mao Q, Zhou D, Li Y, Wang Y, Xu SC, Zhao XH, et al. The Triglyceride-Glucose Index Predicts Coronary Artery Disease Severity and Cardiovascular Outcomes in Patients with NonST-Segment Elevation Acute Coronary Syndrome. Dis Markers 2019;2019:6891537. doi: 10.1155/2019/6891537

28. Won KB, Park EJ, Han D, Lee JH, Choi SY, Chun EJ, et al. Triglyceride glucose index is an independent predictor for the progression of coronary artery calcification in the absence of heavy coronary artery calcification at baseline. Cardiovasc Diabetol 2020;19:34. doi: 10.1186/s12933-020-01008-5 